\title{
Nyersfoszfát- és savkezelés hatása a talajoldat toxikus elem koncentrációira laboratóriumi kísérletben
}

\author{
CSILLAG JULIANNA, LUKÁCS ANDRÁS, OSZTOICS ERZSÉBET, \\ CSATHÓ PÉTER és BACZÓ GYÖNGYI
}

MTA Talajtani és Agrokémiai Kutatóintézet, Budapest

\begin{abstract}
A bázikus kémhatású, üledékes, ún. lágy, reaktív nyersfoszfátok a savanyú talajokba juttatva hatékony P-források lehetnek (BÉSÁNNÉ, 1992; OsZTOICS et al., 2002; GATIBONI et al., 2003; MAGYAR, 2005). Mezőgazdasági alkalmazásuk főbb elönyei:

- A talajban lassan, fokozatosan feltáródó P-vegyületeket tartalmazó üledékes nyersfoszfátok hosszabb távon biztosíthatják a növények P-szükségletét, mint a vízoldható P-mütrágyák (RAJAN et al., 1996).

- Ellentétben a szabad savat tartalmazó P-mütrágyákkal (pl. szuperfoszfát), a nyersfoszfátok jelentős mésztartalmuk miatt, valamint a P-ásvány oldódásakor lejátszódó protonfogyasztó folyamatok révén növelik a talaj $\mathrm{pH}$-ját, mérséklik a talaj savasodásával járó káros hatásokat (BOLAN et al., 2003a; OsZTOICS et al., 2003).

- A közvetlenül a talajba juttatott, olcsóbb, de agronómiailag hatékony nyersfoszfátok a savas feltárással iparilag előállított, drága szuperfoszfátokkal összevetve gazdaságos P-források lehetnek savanyú talajokon, különösen a hosszabb életciklusú, évelő növények termesztésekor (RAJAn et al., 1996; NÉMETH et al., 2002; OszTOICs et al., 2002).

A nyersfoszfátok azonban, a legtöbb P-mütrágyához hasonlóan, P-tartalmuk mellett - eredetüktől és lelőhelyüktől függően - potenciálisan toxikus elemeket, nehézfémeket is tartalmaznak (KÁDÁR, 1991; KPOMBLEKOU \& TABATABAI, 1994; RAVEN \& LOEPPERT, 1997; VAN KAUWENBERGH, 1997; BOLAN et al., 2003b), ezért szükséges vizsgálni talajszennyező hatásukat, szennyező anyagaik táplálékláncba jutásának kockázatát.

A mezőgazdasági gyakorlatban alkalmazott mütrágyák max. megengedett toxikuselem-tartalmát az 50/2003 FVM sz. rendelettel módosított 8/2001 FVM sz. rendelet szabályozza. (2004 májusától Magyarországon mint EU-tagállamban az „EK műtrágyaként” forgalmazott mütrágyák esetében a 2003/2003/EK rendelet értelmében nincs toxikus elemekre vonatkozó határérték elöírva.) A P-mütrágyák szennyező anyagai közül a kadmium a legveszélyesebb, de a hazai talajok 70-es és 80-as években végzett P-feltöltésekor az alkalmazott magmás Kola-nyersfoszfát
\end{abstract}

Postai cím: CSILLAG JULIANNA, MTA Talajtani és Agrokémiai Kutatóintézet, 1022 Budapest, Herman Ottó út 15.E-mail: csillag@rissac.hu 
alapú szuperfoszfát gyakorlatilag nem szennyezte talajainkat kadmiummal (KÁDÁR, 1991, 2005; CSATHÓ, 1994). A 2001-2003-ban végzett vizsgálat szerint a hazai szántóföldi talajokban mért átlagos Cd-tartalom: $0,1-0,5 \mathrm{mg} \cdot \mathrm{kg}^{-1}$ (MÁTHÉNÉ et al., 2004). A szuperfoszfát Sr-tartalma viszont magas (1\% körüli) volt (KÁDÁR, 1991), ami előidézhette a stroncium felhalmozódását a talajban, felvehetővé válását a növény számára. Savanyú talajokon végzett tenyészedény-kísérletben igazolódott a Kola-szuperfoszfátnak a növényi Sr-felvételt növelő hatása (OszToICs et al., 2003), szabadföldi tartamkísérlet 5. évében pedig a talaj Lakanen-Erviö módszerrel meghatározott Sr-tartalmának növekedése volt kimutatható (NÉMETH et al., 2002).

Az Országos Mủtrágyázási Tartamkísérletek (OMTK) talajain 28 éves NP(szuperfoszfát)K mütrágyázás hatását elemezve a talajok EDTA-oldható $\mathrm{Cd}$ - és $\mathrm{Pb}$ tartalmában statisztikailag igazolható változás nem volt kimutatható, koncentrációjuk a megengedett határértékeket meg sem közelítette. Így környezetkárosító hatást, felvehető formába kerülő talajszennyezést nem okozott a Kola-apatitból elóállított P-mütrágya alkalmazása (DEBRECZENI et al., 2000; DEBRECZENINÉ \& LEHOCZKY, 2002). A közel másfélszáz éve tartó Rothamsted-i szabadföldi kísérletben viszont az évek során különbözö Cd-tartalmú (pl. 1925 és 1988 között 3-47 mg Cd· $\mathrm{kg}^{-1}$ ) szuperfoszfát-mütrágyával tartósan kezelt parcellákon - a kezeletlenekkel összevetve - a gyepnövények megnövekedett Cd-felvételét mutatták ki (NICHOLSON et al., 1994). A rendszeresen alkalmazott meszezés a talaj $\mathrm{pH}$-ját jelentősen növelte, a növényi Cd-felvételt csökkentette. Tenyészedény-kísérletek is igazolják, hogy a meszezés, a kémhatás változása meghatározó jelentőségü a kadmium oldhatósága, és ezzel a növényi felvétel szempontjából (JÁSZBERÉNYI, 1979; LEHOCZKY, 2003).

A nyersfoszfátokból agresszív, erős savas feltárással állítják elő a szuperfoszfátmütrágyákat, így azok szabad savtartalmuk révén a talajok savasodását, a korábban a területre került potenciálisan káros, esetleg toxikussá válható elemek, például a nehézfémek oldhatóbbá válását idézhetik elő (STEFANOVITS \& VÁRALLYAY, 1998). $30 \mathrm{~kg} \mathrm{P} \cdot \mathrm{ha}^{-1} \cdot \mathrm{é}^{-1}$ szuperfoszfátadaggal, a műtrágya oldódásakor $0,5 \mathrm{kmol} \mathrm{H^{+ }}$ kerül egy hektár területre (BOLAN et al., 2003a).

A P-trágyázás által közvetve okozott környezeti károk becslése szempontjából fontos annak ismerete, hogy a talaj pH-jának változásakor a talajban jelenlevő, vagy szennyező anyagként bevitt elemek mekkora hányada jelenik meg a talaj folyadékfázisában, hiszen a talajoldatban levő formák azok, melyek legközvetlenebbül hozzáférhetők a növények számára. Arra vonatkozóan találhatók szakirodalmi adatok, hogy a különbözö oldható P-mütrágyák adagolása hogyan befolyásolja a talajoldat mikrotápelem-, illetve toxikus nehézfém koncentrációját (BIERMAN et al., 1995; TAYLOR \& PERCIVAL, 2001). Szükséges vizsgálni a talajok fokozódó savasodása miatt felértékelődő, savas feltárást nem igénylő, közvetlenül alkalmazható bázikus nyersfoszfátok hatását is a folyadékfázis kémhatására, kémiai összetételére. Ezért egy savanyú kémhatású homoktalajt egy üledékes, bázikus nyersfoszfát növekvő adagjaival kezeltünk és meghatároztuk a talajoldat nehézfém- és egyéb potenciálisan toxikus elem koncentrációinak változását. Mértük azt is, hogy mekkora savadag szükséges a talajoldat megnövekedett $\mathrm{pH}$-jának ismét az eredeti pH-értékre való csökkentéséhez. 


\section{Anyag és módszer}

A kísérletben vizsgált, Nyírlugosról származó talaj szántott rétegéből $(0-20 \mathrm{~cm})$ vett minta fontosabb kémiai és fizikai jellemzői: $\mathrm{pH}\left(\mathrm{H}_{2} \mathrm{O}\right): 5,0 ; \mathrm{pH}(\mathrm{KCl}): 3,8 ; \mathrm{y}_{1}$ (hidrolitos savanyúság): $11 ; \mathrm{y}_{2}$ (kicserélhető savanyúság): 3,7; humusztartalom: 0,6\%; T-érték (kationcsere kapacitás): $3,0 \mathrm{cmol} \cdot \mathrm{kg}^{-1}$ talaj; Olsen-P: $16 \mathrm{mg} \cdot \mathrm{kg}^{-1}$ talaj; < 0,02 mm (leiszapolható rész = iszap+agyag): 5,0 tömeg \%; <0,002 mm (agyagfrakció): 2,2 tömeg \%; térfogattömeg: $1,5 \mathrm{~g} \cdot \mathrm{cm}^{-3}$.

A szokásos módon előkészített légszáraz talaj és a Szenegálból származó nyersfoszfát őrölt mintájának (szemcseméret $<500 \mu \mathrm{m}$ ) - 2, ill. 5 ismétlésben - salétromsav+peroxidos roncsolással készített 1:50 arányú kivonatában ICP spektrometriás módszerrel határoztuk meg a nehézfémek és egyéb potenciálisan toxikus elemek mennyiségét (1. táblázat). A vizsgált elemek közül a legtöbb ( $\mathrm{As}, \mathrm{Ba}, \mathrm{Cd}, \mathrm{Cr}, \mathrm{Cu}$, $\mathrm{Hg}, \mathrm{Ni}, \mathrm{Pb}, \mathrm{Zn}$ ) a legismertebb szervetlen szennyezők közé tartozik (RAVEN \& LOEPPERT, 1997; MCGRATH, 2005).

A nyersfoszfátmintát növekvő adagokban (2. táblázat) kevertük 1-1 kg légszáraz talajhoz. A nyersfoszfáttal a talajba juttatott szennyező elemek mennyisége $1500 \mathrm{mg} \mathrm{P}_{2} \mathrm{O}_{5} \cdot \mathrm{kg}^{-1}$ talaj (d2) nyersfoszfátdózis esetén például: $\mathrm{Ba}: 370, \mathrm{Cd}: 415$, Co: 12, Cr: 590, Cu: 220, Mn: 610, Mo: 12, Ni: 160, Pb: 22, Sr: 3610, Zn: 2580 $\mu \mathrm{g} \cdot \mathrm{kg}^{-1}$ talaj volt.

A kontroll- és a nyersfoszfáttal kezelt mintákat különböző koncentrációjú $\mathrm{HNO}_{3}$ oldatokkal (2. táblázat) szabadföldi vízkapacitásra (-10 kPa vízpotenciál, 26,5 tömeg\% nedvességtartalom) nedvesítettük be. A d2 és d4 nyersfoszfátadag esetén öt savterhelést alkalmaztunk (1. ábra, 4. táblázat) és az ac3 savadaggal kezeltük az öt növekvő nyersfoszfátadaggal kezelt talajt (1. ábra, 3. ábra) (összesen 15 kezelés, két ismétlésben).

Egy hétig tartó inkubálás (közben három átkeverés) után centrifugálással választottuk el a növények konvencionális hervadáspontjánál (-1500 kPa vízpotenciál) gyengébben kötött, a növény számára hasznosítható talajoldatot (CSILLAG et al., 1999). Meghatároztuk a talajoldat pH-ját és ICP méréssel As-, Ba-, Cd-, Co-, Cr-, Cu-, Hg-, Mn-, Mo-, Ni-, Pb-, Sr- és Zn-koncentrációját. A számításokhoz, illetve a táblázatok és ábrák készítéséhez a két párhuzamos mérés átlagolt adatait használtuk. A pH-értékeket a protonaktivitások átlagolásával számítottuk. A nyersfoszfáttal kezelt talajon (a d2-ac3 kezelésnél) öt párhuzamos méréssel meghatároztuk a talajoldat-kinyerés módszerének reprodukálhatóságát. A mintaelőkészítés, a folyadékfázis-elválasztás és a kémiai elemzés együttes hibáját kifejező variációs koefficiens (CV) értéke a Cd és Ni elemek esetén nem haladta meg az 5\%-ot, a Ba, Co, $\mathrm{Cu}, \mathrm{Mn}, \mathrm{Sr}$ és $\mathrm{Zn}$ esetén 7 és $20 \%$ között volt, a Cr- és Pb elemeknél pedig 30\%nak adódott. 

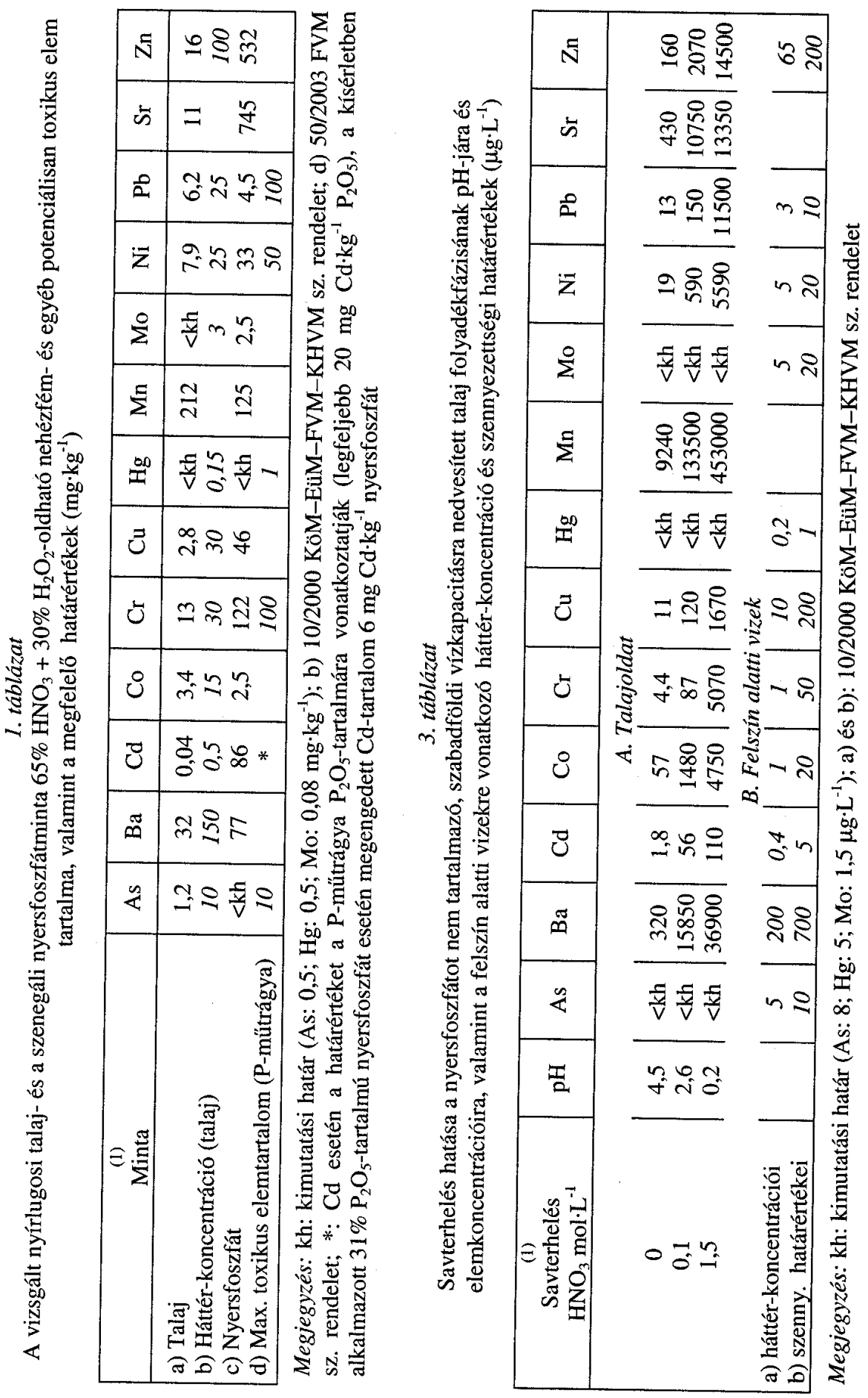
2. táblázat

A kísérletben alkalmazott nyersfoszfát- és savadagok

\begin{tabular}{|c|c|c||c|c|}
\hline $\begin{array}{c}(1) \\
\text { Nyersfoszfát- } \\
\text { adag }\end{array}$ & $\begin{array}{c}(2) \\
\mathrm{m} \mathrm{P}_{2} \mathrm{O}_{5} \cdot \mathrm{kg}^{-1} \\
\text { talaj }\end{array}$ & $\begin{array}{c}(3) \\
\text { g nyersfoszfát } \cdot \mathrm{kg}^{-1} \\
\text { talaj }\end{array}$ & $\begin{array}{c}(4) \\
\text { Savadag }\end{array}$ & $\mathrm{HNO}_{3} \mathrm{~mol} \cdot \mathrm{L}^{-1}$ \\
\hline $\mathrm{d} 0$ & 0 & 0 & $\mathrm{ac0}$ & 0 \\
$\mathrm{~d} 1$ & 750 & 2,43 & $\mathrm{ac} 1$ & 0,05 \\
$\mathrm{~d} 2$ & 1500 & 4,85 & $\mathrm{ac} 2$ & 0,075 \\
$\mathrm{~d} 3$ & 2250 & 7,28 & $\mathrm{ac} 3$ & 0,1 \\
$\mathrm{~d} 4$ & 3000 & 9,70 & $\mathrm{ac} 4$ & 1,5 \\
\hline
\end{tabular}

Megjegyzés: A Szenegálból származó nyersfoszfát megőrölt mintájának $\mathrm{P}_{2} \mathrm{O}_{5}$-tartalma: $31 \%$. Savterhelés: a légszáraz talaj + nyersfoszfát keverék benedvesítése szabadföldi vízkapacitásnak (-10 kPa vízpotenciálnak) megfelelő 26,5 tömeg\% nedvességtartalomra a $\mathrm{HNO}_{3}$ oldatokkal

\section{Eredmények és értékelés}

\section{A nyersfoszfátminta meszezési egyenértéke}

A nyersfoszfátminta salétromsav+peroxidos roncsolással meghatározott összesP-tartalma 13,5\% volt, a Scheibler-módszerrel mért, $\mathrm{CaCO}_{3}$-ban kifejezett összeskarbonát-tartalma pedig 9,9\%. Ezek az értékek a KPOMBLEKOU és TABATABAI (1994) által vizsgált 12 különböző eredetü nyersfoszfátminta vizsgálati adatainak tartományába estek. A kísérletben alkalmazott nyersfoszfát $\mathrm{pH}\left(\mathrm{H}_{2} \mathrm{O}\right)=8,5$ értéke viszont az általuk megadott $\mathrm{pH}$-értékek többségénél magasabb volt.

A P- és $\mathrm{CaCO}_{3}$-tartalomból BoLAN és munkatársai (2003a) módszerével számítottuk a vizsgált nyersfoszfát „meszezési egyenértékét” (liming value): azt a $\mathrm{CaCO}_{3}$ egyenértéksúlyában kifejezett, becsült savmennyiséget, mely egy tonna nyersfoszfátban levő apatit és szabad $\mathrm{CaCO}_{3}$ oldódásakor semlegesítődik. Feltételezve, hogy a nyersfoszfátból származó $1 \mathrm{~kg}$ foszfor $3,2 \mathrm{~kg} \mathrm{CaCO}$-nak megfelelő meszezési egyenértéket biztosít (RAJAN et al., 1996; BOLAN et al., 2003a), a minta teljes meszezési egyenértéke $530 \mathrm{~kg} \mathrm{CaCO}_{3} \cdot$ tonna $^{-1}$ nyersfoszfátnak adódott. (Ez az érték hasonló a BOLAN et al. (2003a) által kb. 10-féle nyersfoszfátmintából számított 450-540 tartomány felső értékeihez).

A talaj- és a nyersfoszfátminta nehézfém- és egyéb potenciálisan toxikus elem tartalma

A nehézfémek és egyéb potenciálisan toxikus elemek mennyisége a kezeletlen talaj salétromsav+peroxidos roncsolással készített kivonatában jóval (a $\mathrm{Cd}$ esetén pl. egy nagyságrenddel) kisebb volt, mint a magyarországi talajok háttér koncentrációja (1. táblázat). A nyersfoszfátminta $\mathrm{Cr}$ - és főleg Cd-tartalma azonban jelentősen meghaladta a szigorú hazai (50/2003 FVM sz.) rendeletben a P-mütrágyákra meg- 
engedett szennyezettségi értékeket. VAN KAUWENBERGH (1997) 207 üledékes nyersfoszfát minta átlagos Cd-tartalmaként $21 \mathrm{mg} \mathrm{Cd} \cdot \mathrm{kg}^{-1}$ nyersfoszfát értéket adott meg, mely erősen szennyezett minták adatait is tartalmazta. A Szenegálból származó mintákban például átlagosan $87 \mathrm{mg} \mathrm{Cd} \cdot \mathrm{kg}^{-1}$ nyersfoszfát volt, ami közel azonos az általunk alkalmazott nyersfoszfátminta Cd-tartalmával (1. táblázat). Egyes nyersfoszfátokban a $100 \mathrm{mg} \mathrm{Cd} \cdot \mathrm{kg}^{-1}$ nyersfoszfát feletti koncentrációk is előfordulnak (VAn KaUwenberg, 1997; Kabata-Pendias \& Pendias, 2001).

A kezeletlen talaj folyadékfázisában mért koncentrációk a kobalt kivételével közel azonosak vagy kisebbek voltak a felszín alatti vizekre megadott szennyezettségi határértékeknél, a háttér-koncentrációkat azonban többnyire meghaladták (3. táblázat).

\section{A talajoldat pH-jának és potenciálisan toxikus elem koncentrációinak sav hatására történö változása}

Az alkalmazott savadagok (föként a 0,1 és $1,5 \mathrm{~mol} \mathrm{HNO}_{3} \cdot \mathrm{L}^{-1}$ koncentrációjú ol-

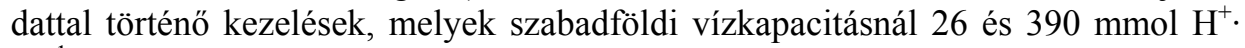
$\mathrm{kg}^{-1}$ talaj terhelésnek felelnek meg) extrém nagy savterheléseket képviselnek: az 1980-as évek intenzív mütrágyázási gyakorlatához kötődő magyarországi becsült átlagos savterhelésnek $\left(7,5 \mathrm{kmol} \mathrm{H} \cdot \mathrm{ha}^{-1} \cdot \mathrm{év}^{-1}\right.$ (MURÁNYI \& RÉDLYNÉ, 1986), azaz átszámítva $2,5 \mathrm{mmol} \mathrm{H}^{+} \cdot \mathrm{kg}^{-1}$ talaj) több, mint 10-, illetve 155 -szörösei.

$\mathrm{Az}$ oldat $\mathrm{H}^{+}$-koncentrációjának növekedésekor, a talajrészecskék felületi töltésének, és ezzel a talaj kationmegkötő képességének csökkenésével (FILEP \& RÉDLYNÉ, 1987-1988) - a szakirodalmi adatokkal egyezően (CSILLAG et al., 1999; KABATA-PENDIAS \& PENDIAS, 2001; BOLAN et al., 2003a) - a talajoldatban a kationt képző elemek mennyisége jelentősen, a nagy savadagoknál több nagyságrenddel nőtt a desztillált vizes kezeléshez képest (3. táblázat). A $0,1 \mathrm{~mol} \mathrm{HNO}_{3} \cdot \mathrm{L}^{-1} \mathrm{kon}$ centrációjú oldattal történő kezeléskor a vizsgált talajban igen kis mennyiségben jelenlevő kadmium (1. táblázat) talajoldatban mért koncentrációja a kontrollmintához viszonyítva $\left(1,8 \mu \mathrm{g} \cdot \mathrm{L}^{-1}\right.$; kimutatási határ $\left.1 \mu \mathrm{g} \cdot \mathrm{L}^{-1}\right)$ a talajoldat $\mathrm{pH}$-értékének két egységnyi csökkenése során kb. 30-szorosára nőtt (3. táblázat). A legnagyobb savterhelés (ac4, 2. táblázat) a legkevésbé mozgékony krómot és ólmot mobilizálta legnagyobb mértékben: koncentrációjuk ezerszeresen meghaladta a kontrollminta folyadékfázisában mértet, míg a többi elemnél 30-300-szoros koncentrációnövekedést idézett elő (3. táblázat).

Az aniont képző elemek (As, Mo) koncentrációja a savanyú kémhatású talajoldatban a kimutatási határ alatt volt (3. táblázat). Ismert, hogy a pH csökkenésével ezek oldhatósága általában csökken (KABATA-PENDIAS \& PENDIAS, 2001; BOLAN et al., 2003a).

Nyersfoszfát-kezelés hatása a talajoldat pH-jára és potenciálisan toxikus elem koncentrációira 
A kísérletben alkalmazott nyersfoszfátadagok (2. táblázat) igen jelentősek, egykét nagyságrenddel meghaladják az intenzív mütrágyázás során kiadott dózisokat is

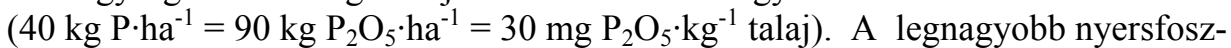

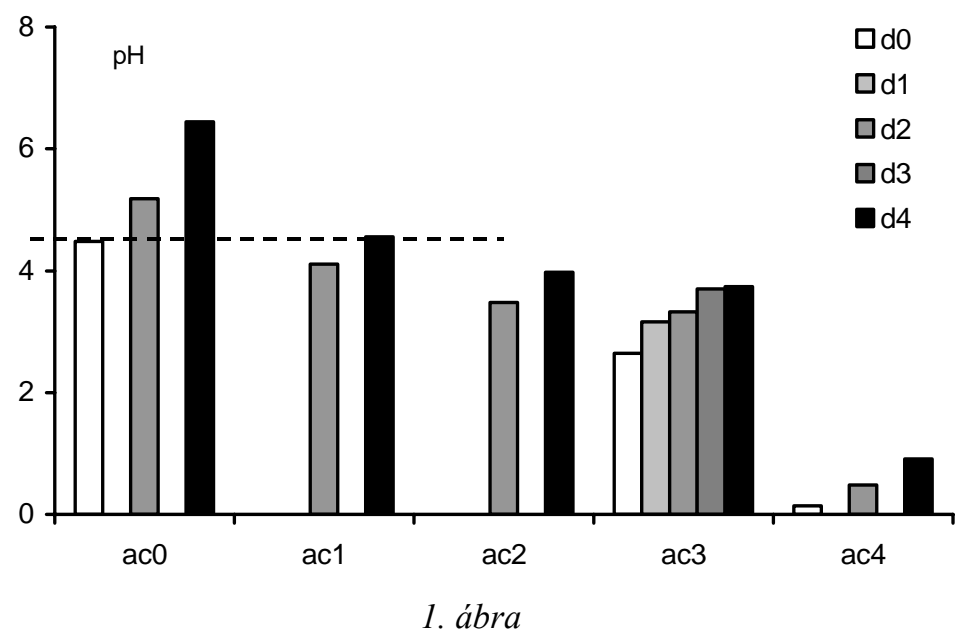

A talajoldat pH-jának változása különböző nyersfoszfátadagok és növekvő savterhelés hatására. d0-d4 és ac0-ac4: lásd 2. táblázat; szaggatott vonal: a talajoldat eredeti $\mathrm{pH}$-ját visszaállító (a d4 nyersfoszfátadag pH-növelő hatását kiegyenlítő) savadag (ac1) alkalmazásakor mért pH. Megjegyzés: az ac1 és ac2 savterhelés esetén csak a d2 és d4 nyersfoszfátadaggal kezelt talajokat vizsgáltuk

fátadag $(\mathrm{d} 4,2$. táblázat) a savanyú homoktalaj folyadékfázisának pH-ját $(4,5) \mathrm{kb}$. két egységgel, a semlegeshez közeli kémhatásúra $(\mathrm{pH}=6,4-\mathrm{re})$ növelte. Ezt már a legkisebb alkalmazott savadag kiegyenlítette ( $\mathrm{acl}=13 \mathrm{mmol} \mathrm{H}^{+} \cdot \mathrm{kg}^{-1}$ talaj; 1 . ábra).

A nyersfoszfát pH-növelö, a kationt képző elemeket immobilizáló hatása (BOLAN et al., 2003b; BASTA \& MCGOWEN, 2004) következtében a nehézfémek és egyéb toxikus elemek talajoldatban mért koncentrációja többnyire csökkent. A kontrollmintáéhoz (d0) viszonyítva a közepes (d2) nyersfoszfátadag alkalmazásakor mindegyik vizsgált elemnél kisebb-nagyobb mértékü koncentrációcsökkenés volt kimutatható, és ez a tendencia több elemnél ( $\mathrm{Ba}, \mathrm{Cd}$, $\mathrm{Co}, \mathrm{Mn}, \mathrm{Pb}, \mathrm{Sr}$ és $\mathrm{Zn}$ ) a legnagyobb nyersfoszfátadag bevitelével tovább folytatódott (2. ábra). Mindez azt jelenti, hogy az alkalmazott kísérleti körülmények között a növekvő nyersfoszfátada-gokkal bevitt szennyezőanyag-mennyiség kevésbé befolyásolta a talajoldatban az elemkoncentrációkat, mint a nyersfoszfát pH-növelö, mobilitást csökkentő hatása.

Az aniont képző molibdén mennyisége a talajoldatban ezzel szemben csak a legnagyobb (d4) nyersfoszfátadagnál haladta meg az $1,5 \mu \mathrm{g} \cdot \mathrm{L}^{-1}$ kimutatási határt, elérve ekkor az 1,9 $\mu \mathrm{g} \cdot \mathrm{L}^{-1}$ koncentrációt. A molibdén megjelenése a folyadékfázis- 

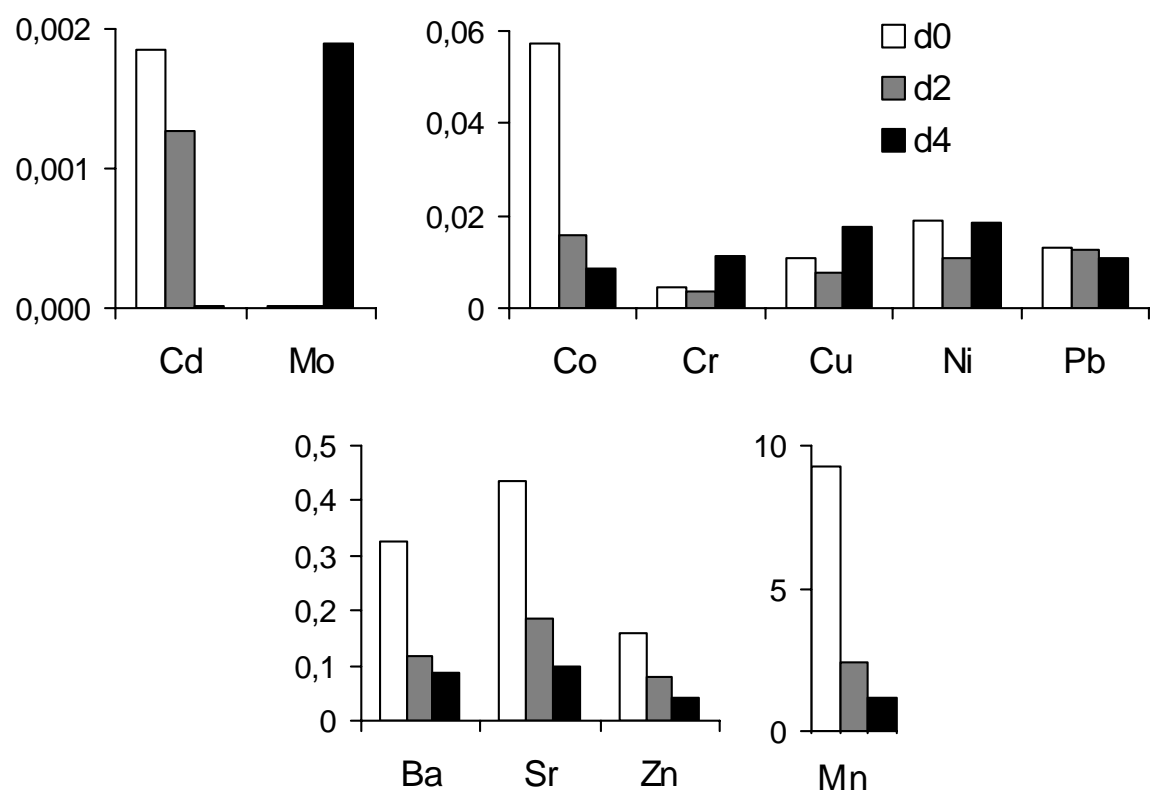

2. ábra

Elemkoncentrációk a talajoldatban $\left(\mathrm{mg} \cdot \mathrm{L}^{-1}\right)$ növekvő nyersfoszfátadagok esetén d0, d2, d4: lásd 2. táblázat; a nyersfoszfátadagok alkalmazásakor a talajoldat pH-értékei: lásd 1. ábra, ac0-kezelés

ban részben az oldat $\mathrm{pH}$-jának növekedésével, ill.a nyersfoszfáttal a talajhoz adott kismennyiségủ molibdén beoldódásával magyarázható. [Savanyú talajokban a Mo, mint mikrotápelem növényi felvehetőségének növelése a pH növelésével, meszezéssel érhető el (KABATA-PENDIAS \& PENDIAS, 2001; BOLAN et al., 2003a).]

Nyersfoszfát- és savkezelés együttes hatása a talajoldat pH-jára és potenciálisan toxikus elem koncentrációira

Azokban a nyersfoszfátot tartalmazó mintákban, amelyeknél a talaj benedvesítésére (desztillált víz helyett) savoldatot használtunk, a Mo-koncentráció a talajoldatban ismét a kimutatási határ alá csökkent.

A nyersfoszfáttal bevitt, illetve a talajban jelenlevő kationok oldhatóságát viszont jelentősen megnövelték az alkalmazott savadagok. A nehézfémek és egyéb toxikussá válható fémek mobilizálódásának, folyadékfázisba kerülésének pontosabb jellemzése céljából talajoldatbeli koncentrációjukat a talajban mért összes + a nyers-foszfáttal bevitt mennyiség százalékában fejeztük ki: $\%=100 \mathrm{c}_{\mathrm{to}} /\left(\mathrm{c}_{\mathrm{T}}+\mathrm{c}_{\mathrm{PR}}\right)$. [ $\mathrm{c}_{\mathrm{to}}$ és $\mathrm{c}_{\mathrm{T}}$ : elemkoncentráció a talajoldatban és a talajban, $\mu \mathrm{g} \cdot \mathrm{kg}^{-1}$ talaj; $\mathrm{c}_{\mathrm{PR}}$ : a nyersfoszfát-adagokkal a talajba vitt elem mennyisége, $\mu \mathrm{g} \cdot \mathrm{kg}^{-1}$ talaj.] A képletben a 
talajoldat- koncentrációkat a légszáraz talaj tömegére vonatkoztatva adtuk meg: $\mu \mathrm{g} \cdot \mathrm{kg}^{-1}=\left(\mu \mathrm{g} \cdot \mathrm{L}^{-1} \cdot\right.$ tömegszázalékban kifejezett talajnedvesség-tartalom $) \cdot 100^{-1}$.
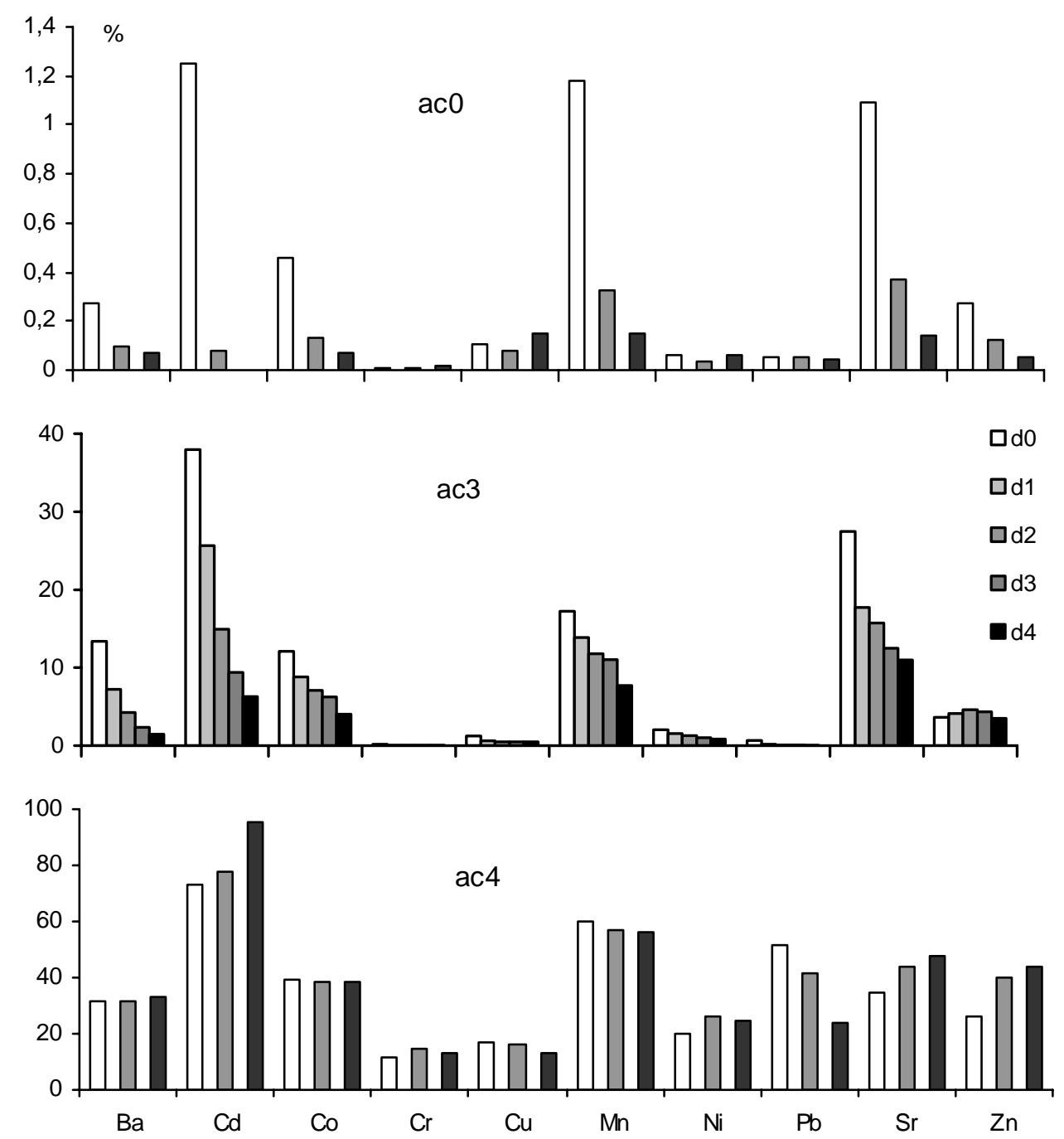

3. ábra

A talajoldatba jutó nehézfémek és egyéb potenciálisan toxikus elemek relatív koncentrációja (\%) növekvő nyersfoszfát- és savadagok esetén. d0-d4 és ac0, ac3, ac4: lásd 2. táblázat; $\%=100 \mathrm{c}_{\mathrm{to}} /\left(\mathrm{c}_{\mathrm{T}}+\mathrm{c}_{\mathrm{PR}}\right)$, ahol $\mathrm{c}_{\mathrm{to}}$ és $\mathrm{c}_{\mathrm{T}}$ : elemkoncentrációk a talajoldatban és a talajban $\left(\mu \mathrm{g} \cdot \mathrm{kg}^{-1}\right.$ talaj); $\mathrm{c}_{\mathrm{PR}}$ : a nyersfoszfátadagokkal a talajba vitt potenciálisan toxikus elemek mennyisége ( $\mu \mathrm{g} \cdot \mathrm{kg}^{-1}$ talaj); d2 adagnál például lásd a szövegben. Megjegyzés: a d1 és d3 nyersfoszfátadagokat csak az ac3 savterhelésnél alkalmaztuk; a különböző kezeléseknek megfelelő talajoldat $\mathrm{pH}$-értékek: lásd 1. ábra 
Növekvő savterheléssel a fémek talajoldatba kerülő relatív mennyisége (\%) nagymértékben nőtt (3. ábra: ac $0<\mathrm{ac} 3<\mathrm{ac} 4$ kezelés, 4. táblázat: $\mathrm{ac} 0<\mathrm{ac} 1<\mathrm{ac} 2<\mathrm{ac} 3$ $<$ ac4 kezelés). Azonban a nyersfoszfát-bevitel következtében - hasonlóan a savterhelést nem kapott mintához (3. ábra, ac0 kezelés) - a savval kezelt minták folyadékfázisában is többnyire csökkent az elemek relatív koncentrációja a kontroll- (nyersfoszfátot nem tartalmazó, d0 jelü) minta folyadékfázisában mért relatív koncentrációkhoz képest (3. ábra: ac3 kezelés, öt nyersfoszfátadag esetén). Megállapítható volt azonban, hogy a savterhelés hatása nagyobb volt, mint a nyersfoszfátkezeléseké.

\section{4. táblázat}

A szenegáli nyersfoszfáttal kezelt talaj (Nyírlugos) folyadékfázisába kerülö nehézfémek relatív koncentrációja (\%) növekvő savterhelésnél

\begin{tabular}{|c|c|c|c|c|c|c|c|c|c|c|}
\hline \multirow{2}{*}{$\begin{array}{c}\text { (1) } \\
\text { Nyers- } \\
\text { foszfát } \\
\text { adag }\end{array}$} & \multicolumn{5}{|c|}{$\begin{array}{c}(2) \\
\text { Savadag }\end{array}$} & \multicolumn{5}{|c|}{$\begin{array}{c}(2) \\
\text { Savadag }\end{array}$} \\
\hline & ac0 & ac1 & $\mathrm{ac} 2$ & ac3 & ac4 & ac0 & $\mathrm{ac} 1$ & ac2 & ac3 & $\mathrm{ac} 4$ \\
\hline & \multicolumn{5}{|c|}{$\mathrm{Cd}$} & \multicolumn{5}{|c|}{$\mathrm{Cr}$} \\
\hline d2 & 0,08 & 5,9 & 11 & 15 & 78 & 0,01 & 0,02 & 0,04 & 0,06 & 14 \\
\hline $\mathrm{d} 4$ & 0 & 2,3 & 4,5 & 6,3 & 95 & 0,02 & 0,02 & 0,02 & 0,05 & 13 \\
\hline $\begin{array}{l}d 2 \\
d 4\end{array}$ & $\begin{array}{l}0,04 \\
0,06\end{array}$ & $\begin{array}{l}0,6 \\
0,5\end{array}$ & $\begin{array}{l}\mathrm{Ni} \\
1,0 \\
0,5\end{array}$ & $\begin{array}{l}1,3 \\
0,8\end{array}$ & $\begin{array}{l}26 \\
25\end{array}$ & $\begin{array}{c}0,1 \\
0,05\end{array}$ & $\begin{array}{l}2,6 \\
2,6\end{array}$ & $\begin{array}{l}\mathrm{Zn} \\
3,6 \\
2,4\end{array}$ & $\begin{array}{l}4,5 \\
3,5\end{array}$ & $\begin{array}{l}40 \\
44\end{array}$ \\
\hline
\end{tabular}

Megjegyzés: d2 és d4, valamint ac0-ac4: lásd 2. táblázat; \% magyarázata: lásd 3. ábra

Az igen nagymértékü savterhelés (az 1,5 mol $\mathrm{HNO}_{3} \cdot \mathrm{L}^{-1}$ oldattal történő kezelés: 3. ábra, ac4 savadag) az elemek többségénél kiegyenlítette a nyersfoszfát immobilizáló hatását: a $\mathrm{Ba}, \mathrm{Co}, \mathrm{Cr}, \mathrm{Cu}, \mathrm{Mn}$ és Ni relatív koncentrációja gyakorlatilag nem változott a növekvő nyersfoszfátadagokkal, azaz a két ellentétes hatás (a rendszerbe juttatott, és a nagy töménységü savoldattal oldatba vitt nagyobb mennyiségü szennyező elem és a nyersfoszfát immobilizáló hatása) kiegyenlítette egymást. A Cd-, Sr- és Zn-koncentráció már emelkedett is a növekvő nyersfoszfátadagokkal, a bevitt szennyezö anyag megnövekedett mennyiségének megfelelően. [A cink oldatba kerülő relatív mennyisége - szemben a többi fémével - már a kisebb, ac3 savterhelésnél is kismértékü növekedést mutatott (3. ábra: ac3 kezelés a d0<d1<d2 nyersfoszfátadagnál).]

Csak az ólom esetén maradt hatékony a nyersfoszfát immobilizáló hatása még az extrém savadagnál is: relatív koncentrációja a talajoldatban csökkent a növekvő nyersfoszfátdózisokkal. Az irodalmi adatok (BOLAN et al., 2003b; CAO et al., 2003; BASTA \& MCGOWEN, 2004) is alátámasztják, hogy a nyersfoszfát, illetve a foszfátok immobilizáló hatása leghatékonyabb az ólom esetén.

A 4. táblázatban az öt alkalmazott savadagnál és két nyersfoszfátdózisnál tüntettük fel négy nehézfém mobilizálódott (relatív) mennyiségét. A számszerü értékek is mutatják, hogy a folyadékfázisba kerülő relatív mennyiségek jelentősen nőnek a 
savterhelés növekedésével, különösen a kadmiumé, ugyanakkor a nyersfoszfát nagyobb mennyiségének hozzáadása többnyire csökkenti az oldatba jutó nehézfémmennyiség százalékos értékét. Csak az extrém nagy savterhelésnél, a mozgékony kadmium és cink (valamint a táblázatban nem feltüntetett stroncium) esetén fordult meg ez a tendencia (v.ö. 3. ábra).

A fémek talajoldatbeli koncentrációinak relatív (az összes bevitt mennyiség százalékában kifejezett) értékeit összehasonlítva megállapítottuk, hogy a kezelések többségénél a Cd volt a legmozgékonyabb elem, de jelentős volt a mangán és stroncium moblilitása is (3. ábra, 4. táblázat). A legkevésbé mobilis elemnek - ahogy az várható volt - a $\mathrm{Cr}$ bizonyult. A savterheléssel a kadmium, mangán és ólom mobilitása nőtt leginkább, a rézé pedig a többi fémmel összevetve kisebb mértékben (3. ábra, 4. táblázat).

\section{Következtetés}

A vizsgált kísérleti rendszerben mért adatok alapján (a nyersfoszfát egyszeri nagy adagjának alkalmazásakor, egy hetes inkubálást végezve) megállapítottuk, hogy bár a nyersfoszfáttal nehézfémeket is juttattunk a talajba, a nyersfoszfát immo-bilizáló hatása és a savanyú talaj kémhatásának a semleges felé történő eltolódása miatt az elemeknek csak igen kis hányada került a talaj folyadékfázisába. Ez a mennyiség a nyersfoszfátot nem tartalmazó kontroll talajmintához képest többnyire csökkent. Extrém nagy savterhelés volt szükséges a talaj+nyersfoszfát rendszer nehézfémtartalmának oldatba viteléhez. A nyersfoszfát, mint P-forrás hosszabb távú szennyező hatásának vizsgálatához további tenyészedény- és szabadföldi tartamkísérletek szükségesek.

\section{Összefoglalás}

A bázikus kémhatású, üledékes nyersfoszfátok a savanyú talajokba juttatva hatékony P-források lehetnek. Felhasználásukat környezetvédelmi szempontból korlátozhatja, hogy P-tartalmuk mellett - eredetüktől és lelőhelyüktől függően - szenynyeződésként nehézfémeket és egyéb toxikussá válható elemeket tartalmazhatnak. A nehézfémek oldódását, talajoldatba kerülését nagymértékben befolyásolja a talaj savassága, ezért fontos annak ismerete, hogy a talaj pH-jának változásakor a talajban jelenlevő, vagy szennyező anyagként bevitt elemek mekkora hányada jelenik meg a talaj folyadékfázisában.

Laboratóriumi kísérletben különböző nyersfoszfátadagok $(0 ; 750 ; 1500 ; 2250$; $3000 \mathrm{mg} \mathrm{P}_{2} \mathrm{O}_{5} \cdot \mathrm{kg}^{-1}$ talaj) és savterhelések $\left(0 ; 0,05 ; 0,075 ; 0,1 ; 1,5 \mathrm{~mol} \cdot \mathrm{L}^{-1} \mathrm{HNO}_{3}\right.$ oldat) alkalmazása esetén szabadföldi vízkapacitásnál meghatároztuk a nyírlugosi savanyú homoktalaj folyadékfázisába jutó $\mathrm{As}, \mathrm{Ba}, \mathrm{Cd}, \mathrm{Co}, \mathrm{Cr}, \mathrm{Cu}, \mathrm{Hg}, \mathrm{Mn}, \mathrm{Mo}, \mathrm{Ni}$, $\mathrm{Pb}, \mathrm{Sr}$ és $\mathrm{Zn}$ elemek mennyiségét. A talajoldatot a növény hervadáspontjának (-1500 kPa vízpotenciálnak) megfelelő fordulatszámú centrifugálással választottuk 
el. A kezeletlen talaj, valamint a Szenegálból származó nyersfoszfát „összes” nehézfém- és egyéb potenciálisan toxikus elem tartalmát salétromsav+peroxidos roncsolás 1:50 arányú kivonatában határoztuk meg.

Megállapítottuk, hogy a bázikus nyersfoszfát adagolása az eredeti és a savval kezelt mintákban is csökkentette a rendszer savasságát, megnövelte a talajoldat $\mathrm{pH}$ ját. Ez a nyersfoszfát jelentős mésztartalmával és a P-ásvány oldódásakor lejátszódó protonfogyasztó folyamatokkal magyarázható, egyezően a szakirodalmi adatokkal. Ezzel összefüggésben a kationképző elemek koncentrációja a nyersfoszfátot tartalmazó talajminták folyadékfázisában többnyire csökkent a kontrollmintáéhoz képest. A nehézfémek talajoldatbeli koncentrációját a talajban mért összes + a nyersfoszfáttal bevitt mennyiség százalékában, relatív koncentrációként kifejezve is kimutattuk, hogy a növekvő nyersfoszfátadagokkal bevitt szennyezőanyagmennyiség általában kevésbé befolyásolta a talajoldatban az elemkoncentrációkat, mint a nyersfoszfát $\mathrm{pH}$-növelö, mobilitást csökkentő hatása.

Az igen nagymértékủ savterhelés az elemek többségénél kiegyenlítette ezt a hatást: a $\mathrm{Ba}, \mathrm{Co}, \mathrm{Cr}, \mathrm{Cu}, \mathrm{Mn}$ és Ni relatív koncentrációja gyakorlatilag nem változott a növekvö nyersfoszfátadagokkal, a $\mathrm{Cd}$, Sr és $\mathrm{Zn}$ koncentrációja pedig növekedett. Csak az ólom esetén maradt meg a nyersfoszfát immobilizáló hatása még az extrém savadagnál is, relatív koncentrációja csökkent a növekvő nyersfoszfátdózisokkal.

A nehézfémek relatív koncentrációit összevetve, a kezelések többségénél a $\mathrm{Cd}$, Mn és Sr volt a legmozgékonyabb elem, a legkevésbé mobilisnak pedig - ahogy az várható volt - a Cr bizonyult. $\mathrm{Az}$ anionképző elemek (As, Mo) koncentrációja a legnagyobb nyersfoszfátadag esetén is elhanyagolható, vagy kimutatási határ alatti volt a savanyú kémhatású talajoldatban.

A kísérlet alapján azt a következtetést vontuk le, hogy bár a nyersfoszfáttal nehézfémeket is a talajba juttatunk, a nyersfoszfát immobilizáló hatása, a savanyú talaj kémhatásának a semleges felé történő eltolódása miatt rövid idejű inkubálás esetén ezeknek csak igen kis hányada mobilizálódik, kerül a talaj folyadékfázisába. Extrém nagy savterhelés volt szükséges a talaj+nyersfoszfát rendszer nehézfémtartalmának oldatba viteléhez.

Fenti kutatást az Országos Tudományos Kutatási Alap a T038046 számú szerződés keretében támogatta.

Kulcsszavak: talajoldat, toxikus elem, nyersfoszfát, savkezelés

\section{Irodalom}


BAStA, N. T. \& MCGowen, S. L., 2004. Evaluation of chemical immobilization treatments for reducing heavy metal transport in a smelter-contaminated soil. Environ. Pollut. 127. 73-82.

BÉSÁN J.-NÉ, 1992. Nyersfoszfát bázisú mütrágyák szerepe a gazdaságos mütrágyázásban. Agrofórum. Különszám. 1992/1. 41-43.

BIERMAN, P. M. et al., 1995. Soil solution chemistry of sewage-sludge incinerator ash and phosphate fertilizer amended soil. J. Environ. Qual. 24. 279-285.

Bolan, N. S., Adriano, D. C. \& CURTIN, D., 2003a. Soil acidification and liming interactions with nutrient and heavy metal transformation and bioavailability. Adv. Agron. 78. 215-272.

BOlan, N. S., ADRIANO, D. C. \& NAIDU, R., 2003b. Role of phosphorus in (im)mobilization and bioavailability of heavy metals in the soil-plant system. Rev. Environ. Contam. Toxicol. 177. 1-44.

CAO, R. X. et al., 2003. Phosphate-induced metal immobilization in a contaminated site. Environ. Pollut. 122. 19-28.

CSATHÓ P., 1994. A környezet nehézfém szennyezettsége és az agrártermelés. Tematikus szakirodalmi szemle. MTA TAKI. Budapest.

CSILlaG, J. et al., 1999. Extraction of soil solution for environmental analysis. Intern. J. Environ. Anal. Chem. 74. 305-324.

DEBRECZENI B.-NÉ \& LEHOCZKY É., 2002. Tartam mütrágyázás hatása a talajok toxikus nehézfémtartalmára. In: XVI. Országos Környezetvédelmi Konferencia. (Szerk.: ELEK GY. \& VÉCSI B.) 180-186. Siófok.

DeBreCZENI, K. et al., 2000. Effect of increasing fertilizer doses on the soluble P, Cd, $\mathrm{Pb}$, and $\mathrm{Cr}$ content of soils. Commun. Soil Sci. Plant Anal. 31. 1825-1835.

FILEP GY. \& RÉDLY L.-NÉ., 1987-1988. A talajsavanyúság formáinak és a talaj savbázis pufferoló hatásának értelmezése. Agrokémia és Talajtan. 36-37. 79-96.

GAtiBOni, L. C. et al., 2003. Superphosphate and rock phosphates as phosphorus sources for grass-clover pasture on a limed acid soil in Southern Brazil. Commun. Soil Sci. Plant Anal. 34. 2503-2514.

JÁSZBERÉNYI I., 1979. Kadmiumhatás-vizsgálatok tenyészedény-kísérletben. Doktori értekezés. DATE Debrecen.

Kabata-Pendias, A. \& Pendias, H., 2001. Trace Elements in Soils and Plants. $3^{\text {rd }}$ ed. CRC Press. Boca Raton.

KÁDÁR I., 1991. A talajok és növények nehézfémtartalmának vizsgálata. Környezet- és természetvédelmi kutatások. KTM-MTA TAKI. Budapest.

KÁDÁR I., 2005. A talaj és a tápláléklánc szennyeződése. In: Talajtani Vándorgyülés (Szerk.: ANTAl K., MichÉLi E. \& SzABÓNÉ KelE G.) 129-137. Talajvédelmi Alapítvány. Budapest.

KpombleKOU, K. \& TABATABAi, M. A., 1994. Metal contents of phosphate rocks. Com-mun. Soil Sci. Plant Anal. 25. 2871-2882.

LEHOCZKY É., 2003. A növényi kadmiumfelvétel tanulmányozása meszezési kísérletben. In: Mikroelemek a táplálékláncban. (Szerk.: SiMON L. \& SzILÁGYI M.) 157165. Bessenyei György Könyvkiadó. Nyíregyháza.

MAGYAR M., 2005. A foszfor felvehetőségének vizsgálata jellegzetes hazai talajokon. $\mathrm{PhD}$ disszertáció. Szent István Egyetem. Gödöllő. 
MCGRATH, S. P., 2005. Pollution/industrial. In: Encyclopedia of Soils in the Environment. (Eds.: Hillel, D. et al.) 282-287. Elsevier Academic Press. Amsterdam.

MÁTHÉNÉ GÁSPÁR G. et al., 2004. Kadmium-szennyezés utóhatása a talajra és növényekre egy barna erdőtalajon. Agrokémia és Talajtan. 53. 143-154.

MURÁNYI A. \& RÉDLY L.-NÉ, 1986. Titrálási görbék felhasználása a talajt érő savterhelések hatásának összehasonlító jellemzésére. Agrokémia és Talajtan. 35. 49-62.

NÉMETH, T. et al., 2002. Long-term field evaluation of phosphate rock and superphosphate use strategies in acid soils of Hungary: Two comparative field trials. Nutr. Cycl. Agroecosys. 63. 81-89.

Nicholson, F. A., Jones, K. C. \& Johnston, A. E., 1994. Effect of phosphate fertilizers and atmospheric deposition on long-term changes in the cadmium content of soils and crops. Environ. Sci. Technol. 28. 2170-2175.

OszToICs E. et al., 2002. A nyersfoszfát, mint közvetlen P-trágya alkalmazásának feltételei és agronómiai hatása. Agrokémia és Talajtan. 51. 505-534.

OszToICs E. et al., 2003. Az algériai nyersfoszfát és a szuperfoszfát hatásának vizsgálata III. A talajtulajdonságok, a foszforforma és foszforadag hatása a vörös here Cd-, Cr- és Sr-koncentrációjára tenyészedény-kísérletben. Agrokémia és Talajtan. $\mathbf{5 2}$. 363-382.

RAJAN, S. S. S., WatKinson, J. H. \& SinClaiR, A. G., 1996. Phosphate rocks for direct application to soils. Adv. Agron. 57. 77-159.

RAVEN, K. P. \& LOEPPERT, R. H., 1997. Trace element composition of fertilizers and soil amendments. J. Environ. Qual. 26. 551-557.

Stefanovits P. \& VÁrallyay Gy., 1998. Talajsavanyodás okai, következményei és megelőzésének, megszüntetésének lehetőségei. Gyakorlati Agrofórum. IX. 4/M. 3-7.

TAYloR, M. D. \& Percival, H. J., 2001. Cadmium in soil solutions from a transect of soils away from a fertiliser bin. Environ. Pollut. 113. 35-40.

van Kaumenbergh, S. J., 1997. Cadmium and Other Minor Elements in World Resources of Phosphate Rock. The Fertiliser Society. Proc. No. 400. London.

10/2000. (VI. 2.) A felszín alatti víz és a földtani közeg minőségi védelméhez szükséges határértékekröl. A KöM-EüM-FVM-KHVM együttes rendelete. Magyar Közlöny 2000/53. sz. 3156-3167.

8/2001. (I. 26). A termésnövelő anyagok engedélyezéséről, tárolásáról, forgalmazásáról és felhasználásáról. Az FVM rendelete. Magyar Közlöny 2001/9. sz. 458-522.

50/2003. (V. 9.) A termésnövelő anyagok engedélyezéséről, tárolásáról, forgalmazásáról és felhasználásáról. Az FVM rendelete. Magyar Közlöny 2003/49. sz. 4342 4347.

2003/2003/EK. Az Európai Parlament és a Tanács 2003/2003/EK rendelete (2003. október 13.) a mütrágyákról. Az Európai Unió Hivatalos Lapja. (2003. 11. 21.) L 304 .

Érkezett: 2005. szeptember 7.

\section{Effect of Phosphate Rock and Acid Treatment on Toxic Element}




\title{
Concentrations of the Soil Solution in a Laboratory Experiment
}

\author{
J. CSILLAG, A. LUKÁCS, E. OSZTOICS, P. CSATHÓ and G. BACZÓ
}

Research Institute for Soil Science and Agricultural Chemistry of the Hungarian Academy of Sciences, Budapest

\section{Summary}

Sedimentary, basic phosphate rocks (PRs) may be efficient P fertilizers when applied to acidic soils. However, their use may cause soil contamination as they often contain heavy metals and other potentially toxic pollutants. The mobility of these elements is influenced by soil acidity, so it is necessary to gain information about the amount of pollutants entering the soil solution in PR-treated soil at different $\mathrm{pH}$ values.

In a laboratory bulk experiment, increasing doses of a sedimentary, basic, ground PR (from Senegal, particle size: $<500 \mu \mathrm{m} ; 0,750,1500,2250$ and $3000 \mathrm{mg} \mathrm{P}_{2} \mathrm{O}_{5} \cdot \mathrm{kg}^{-1}$ soil) were added to air-dried samples of an acidic sandy soil (ploughed layer, Nyírlugos, Hungary). PR-enriched soil samples were moistened to field capacity with deionized water or with $\mathrm{HNO}_{3}$ solutions of $0,0.05,0.075,0.1$ and $1.5 \mathrm{~mol} \mathrm{~L}^{-1}$ concentrations. The soil solution was obtained from the wet soil by centrifugation after one week of incubation, by applying a rotor speed corresponding to the suction power exerted by the plant at the conventional wilting point. The $\mathrm{As}, \mathrm{Ba}, \mathrm{Cd}, \mathrm{Co}, \mathrm{Cr}, \mathrm{Cu}, \mathrm{Hg}, \mathrm{Mn}, \mathrm{Mo}, \mathrm{Ni}, \mathrm{Pb}, \mathrm{Sr}$ and $\mathrm{Zn}$ concentrations in the soil solution were determined by ICP spectrometry. The potentially toxic element contents of the soil and the PR sample were also determined using the ICP-AES method in 1:50 extracts of microwave wet digestion carried out in a teflon bomb with concentrated $\mathrm{HNO}_{3}+\mathrm{H}_{2} \mathrm{O}_{2}$ solution.

Due to the application of the PR the soil solution $\mathrm{pH}$ increased and the concentrations of cation-forming elements generally decreased as compared to the untreated control sample. This means that metal concentrations were influenced less by the amounts introduced into the soil with the PR than by the immobilizing effect of the PR. Concentrations of As and Mo were below the detection limit in the acidic soil solutions (control: $\mathrm{pH}=4.5$ ), but at the highest PR dose Mo appeared in the nearly neutral solution $\left(\mathrm{pH}=6.4\right.$; Mo amount introduced into the soil at this PR rate: $24 \mu \mathrm{g} \cdot \mathrm{kg}^{-1}$ soil).

After applying acid loads the concentration of cations increased considerably. In order to compare metal mobilities and obtain an exact picture of their release into the soil solution after various PR and acid treatments, the metal concentrations in the soil solution were expressed as a percentage of their "total" amounts in the soil+PR sample. These relative metal concentrations also increased with acid treatment but, with the exception of the highest acid load, were lowered by increasing PR doses. At the highest acid load the immobilizing effect of PR was only effective in the case of $\mathrm{Pb}$, the relative concentration of which decreased with an increase in PR even in this extremely acid solution. The relative concentrations of $\mathrm{Ba}, \mathrm{Co}, \mathrm{Cr}, \mathrm{Cu}, \mathrm{Mn}$ and $\mathrm{Ni}$ did not change with an increase in the PR dose in this strongly acid medium, which means that the two opposing effects, i.e. the increasing input of pollutants versus the immobilizing effect of $\mathrm{PR}$, compensated each other. The relative concentrations of $\mathrm{Cd}, \mathrm{Sr}$ and $\mathrm{Zn}$ increased 
with increasing PR input, since higher amounts of these metals entered the soil solution from the larger pool of metals at the high acid load.

Comparing the relative metal concentrations for all PR and acid treatments it was shown that under the conditions of the bulk experiment $\mathrm{Cd}, \mathrm{Mn}$ and $\mathrm{Sr}$ were the most mobile elements while, as expected, $\mathrm{Cr}$ was the least mobile.

It was concluded that though the applied PR contained a relatively high amount of potentially toxic elements (Cd: $86, \mathrm{Cr}: 122 \mathrm{mg} \cdot \mathrm{kg}^{-1}$, etc.), due to its immobilizing effect only a small amount of these elements entered the soil solution during the short incubation period in the studied system. In most cases the release of metals into the soil solution was even lower than in the control treatment. Only the addition of extremely strong acid mobilized a relatively high amount of the metals present in the soil+PR system.

Table 1. Heavy metal and other potentially toxic element contents in the Nyírlugos soil and Senegal phosphate rock (PR) sample determined by $65 \% \mathrm{HNO}_{3}+30 \% \mathrm{H}_{2} \mathrm{O}_{2}$ digestion, and the corresponding threshold levels, $\mathrm{mg} \cdot \mathrm{kg}^{-1}$. (1) Sample. a) Soil; b) background concentrations of pollutants in soils in Hungary; c) Phosphate rock; d) max. permitted toxic element contents of $\mathrm{P}$ fertilizers in Hungary. Note: $\mathrm{kh}=$ detection limit (As: 0.5, Hg: 0.5, Mo: $0.08 \mathrm{mg} \cdot \mathrm{kg}^{-1}$ ); b) ministerial decree No. 10/2000 KöM-EüMFVM-KHVM, d) ministerial decree No. 50/2003 FVM. * = in the case of Cd the threshold level is related to the $\mathrm{P}_{2} \mathrm{O}_{5}$ content of the $\mathrm{P}$ fertilizer ( $\max .20 \mathrm{mg} \mathrm{Cd} \cdot \mathrm{kg}^{-1} \mathrm{P}_{2} \mathrm{O}_{5}$ ), meaning that for the applied PR sample containing $31 \% \mathrm{P}_{2} \mathrm{O}_{5}$ the max. permitted $\mathrm{Cd}$ content is $6 \mathrm{mg} \mathrm{Cd} \cdot \mathrm{kg}^{-1} \mathrm{PR}$.

Table 2. Phosphate rock (PR) doses and acid loads applied in the experiment. (1) PR dose. (2) $\mathrm{g} \mathrm{P}_{2} \mathrm{O}_{5} \cdot \mathrm{kg}^{-1}$ soil. (3) $\mathrm{g} \mathrm{PR} \cdot \mathrm{kg}^{-1}$ soil. (4) Acid load.

Table 3. Effect of increasing acid loads on $\mathrm{pH}$ and element concentrations $\left(\mu \mathrm{g} \mathrm{L}^{-1}\right)$ in the liquid phase of the original soil (not containing phosphate rock) moistened to field capacity (A), and threshold levels for subsurface waters (B) $\left(\mu \mathrm{g} \mathrm{L} \mathrm{L}^{-1}\right)$. (1) Acid load. a) Background concentrations; b) tolerable threshold values of pollutants in subsurface waters (ministerial decree No. 10/2000 KöM-EüM-FVM-KHVM). Note: kh = detection limit (As: 8, $\mathrm{Hg}: 5$, Mo: $1.5 \mu \mathrm{g} \cdot \mathrm{L}^{-1}$ ).

Table 4. Relative concentrations of heavy metals (\%) entering the liquid phase of a sandy soil (Nyírlugos) treated with Senegal PR at increasing acid loads. (1) Phosphate rock dose. (2) Acid load. Note: d2, d4 and ac0-ac4: see Table 2; \%: see Fig. 3.

Fig. 1. Changes in soil solution $\mathrm{pH}$ at increasing phosphate rock (PR) doses and acid loads. Note: $\mathrm{d} 0-\mathrm{d} 4$ and ac0-ac4: see Table 2; dashed line: soil solution $\mathrm{pH}$ measured when the acid load (ac1) compensating the pH-elevating effect of the basic PR sample at the $\mathrm{d} 4$ dose was applied; in the case of the 0.05 and $0.075 \mathrm{~mol} \mathrm{HNO} \cdot \mathrm{L}^{-1}$ acid loads (ac1 and ac2, resp.) only PR-treated soils (at doses $\mathrm{d} 2$ and $\mathrm{d} 4$ ) were analyzed.

Fig. 2. Element concentrations $\left(\mathrm{mg} \cdot \mathrm{L}^{-1}\right)$ in the soil solution at increasing phosphate rock (PR) doses. Note: for $\mathrm{d} 0, \mathrm{~d} 2$, d4: see Table 2 ; for soil solution $\mathrm{pH}$ values at the applied PR doses: see ac0 treatment in Fig. 1.

Fig. 3. Relative concentrations of metals (\%) entering the soil solution at increasing phosphate rock (PR) doses and acid loads. Note: for $\mathrm{d} 0-\mathrm{d} 4$ and ac0, ac3 and ac4: see Table 2; Vertical axis: $\%=100 \mathrm{c}_{\mathrm{to}} /\left(\mathrm{c}_{\mathrm{T}}+\mathrm{c}_{\mathrm{PR}}\right)$, where $\mathrm{c}_{\mathrm{to}}$ and $\mathrm{c}_{\mathrm{T}}=$ metal concentrations in the soil solution and in the soil $\left(\mu \mathrm{g} \cdot \mathrm{kg}^{-1}\right.$ soil $) ; \mathrm{c}_{\mathrm{PR}}=$ metal amounts introduced into the soil with PR ( $\mu \mathrm{g} \cdot \mathrm{kg}^{-1}$ soil; at dose $\mathrm{d} 2$ ); the $\mathrm{d} 1$ and $\mathrm{d} 3$ PR doses were applied only in the case of acid load ac3; for soil solution $\mathrm{pH}$ values in the applied treatments see Fig. 1. 